\title{
Global fetal DNA methylation and birth outcomes in obese women
}

\author{
Karla Solheim, MD, ${ }^{1}$ Donna A. Santillan, $\mathrm{PhD},{ }^{1}$ Sabrina Scroggins, $\mathrm{PhD},{ }^{1}$ Eric J. Devor, \\ $\mathrm{PhD},{ }^{1}$ Mark K. Santillan, $\mathrm{MD}^{1}$
}

\begin{abstract}
Keywords: DNA methylation, obesity, respiratory distress syndrome, pregnancy, diabetes,
\end{abstract} maternal, gestational, fetal

\section{Background}

Pregnant women who are obese are more likely to have gestational diabetes, gestational hypertension, pre-eclampsia, macrosomia, operative vaginal delivery, and cesarean delivery. Obesity also has adverse implications for the neonate. Congenital anomalies are more common in children born to obese women. These include neural tube defects, gastroschisis, cardiovascular anomalies, and others. Although the connection between maternal obesity and chronic health conditions has been described, the mechanism by which this occurs is less well understood. Changes to the epigenetic structure of offspring DNA have been proposed as one such mechanism.

\section{Methods}

Cord blood specimens were collected by the Maternal Fetal Tissue Bank (IRB\# 200910784). ( $N=53$ non-obese maternal subjects, $\mathrm{N}=55$ obese subjects). Cord blood DNA was extracted from mononuclear cells using the Genomic DNA Mini-Kit from IBI Scientific. The total amount of methylated DNA in each sample of $200 \mathrm{mg}$ total DNA was calculated using a commercial methylated DNA quantification kit, the Imprint Methylated DNA Quantification Kit (Sigma-Aldrich Scientific). Samples were assayed in duplicate. For both obese and non-obese cohorts, total methylated DNA in a 200 ng sample was calculated as our primary outcome. For secondary outcomes, preeclampsia, prematurity, gestational diabetes, IUGR, PVL, NEC, respiratory distress syndrome (RDS), 5-minute

\footnotetext{
${ }^{1}$ Department of Obstetrics and Gynecology, Carver College of Medicine, University of lowa Hospitals and Clinics, lowa City, IA, 52242

Please cite this abstract as: Solheim K, Santillan DA, Scroggins S, Devor EJ, Santillan MK. Global fetal DNA methylation and birth outcomes in obese women. Proc Obstet Gynecol. 2013;4(3):Article 12 [ 2 p.]. Available from: http://ir.uiowa.edu/pog/. Free full text article.
}

Corresponding author: Karla Solheim, Department of Obstetrics and Gynecology, University of lowa, 200 Hawkins Drive, Iowa City, IA 42242, karla-solheim@uiowa.edu

Copyright: (c) 2014 Solheim, et al. This is an open-access article distributed under the terms of the Creative Commons Attribution License, which permits unrestricted use, distribution, and reproduction in any medium, provided the original author and source are credited. 
Apgars $<7, \quad$ NICU admission, hypoglycemia, and hyperbilirubinemia were analyzed against total fetal DNA methylation to determine whether there was a correlation using bivariate and multivariate regression analysis.

\section{Results}

We did not find a statistically significant relationship between maternal $\mathrm{BMI}$ and cord blood total DNA methylation. For non-obese gravidas, the average total fetal DNA methylation was $7.6 \%$. For obese gravidas, the average total fetal DNA methylation was $6.4 \%$. $(p=0.249)$. In terms of our secondary outcomes, respiratory distress syndrome (RDS) and NICU admission were both significantly associated with decreased global DNA methylation. The secondary outcomes of prematurity, pre-eclampsia, gestational diabetes, IUGR, 5-minute Apgar <7, NICU stay $>24$ hours, hypoglycemia requiring IV dextrose, and hyperbilirubinemia requiring phototherapy did not show a statistically significant correlation to global fetal DNA methylation.

\section{Conclusions}

Although we did not find a relationship between maternal BMI and fetal DNA methylation, this does not rule out the possibility that such a relationship may exist. Our study may have been underpowered to detect such a difference. Our study did show a correlation between neonatal RDS and NICU admission and global DNA hypomethylation. These are promising avenues of future research.

Presented at "Practical Update in Ob/Gyn," the University of Iowa Obstetrics and Gynecology Postgraduate conference, 24 October 2014, hotelVetro \& Conference Center, lowa City, lowa 52240. 